\title{
Menadione Induced Apoptosis in MKN45 Cells via Down-regulation of Survivin
}

\author{
Min Ho Lee, ${ }^{1,+}$, Jeongyong Kim ${ }^{1,2, \dagger}$, Yoonjung $\mathrm{Cho}^{2}$, Do Hyun Kim ${ }^{1}$, Ji Yeong Yang ${ }^{1}$, Hye Jin Kwon ${ }^{1}$,
} Min Park ${ }^{3}$, Hyun Jun Woo ${ }^{4}$, Sa-Hyun Kim ${ }^{5}$, Jong-Bae Kim ${ }^{1}$

\author{
${ }^{1}$ Department of Biomedical Laboratory Science, College of Health Sciences, Yonsei University, Wonju, Korea \\ ${ }^{2}$ Forensic DNA Division, National Forensic Service, Wonju, Korea \\ ${ }^{3}$ Department of Biomedical Laboratory Science, Daekyeung University, Gyeongsan, Korea \\ ${ }^{4}$ Department of Clinical Laboratory Science, College of Medical Sciences, Daegu Haany University, Gyeongsan, Korea \\ ${ }^{5}$ Department of Clinical Laboratory Science, Semyung University, Jecheon, Korea
}

\section{Menadione의 Survivin 하향 조절을 통한 MKN45 세포의 세포사멸 유도 효과}

\author{
이민호 ${ }^{1,2, \dagger}$, 김정용 ${ }^{1,2, \dagger}$, 조윤정 ${ }^{2}$, 김도현 ${ }^{1}$, 양지영 ${ }^{1}$, 권혜진 $^{1}$, 박 $^{\text {민 }}{ }^{3}$, 우현준 $^{4}$, 김사현 $^{5}$, 김종배 ${ }^{1}$ \\ ${ }^{1}$ 연세대학교 보건과학대학 임상병리학과, ${ }^{2}$ 국립과학수사연구원 법유전자과, ${ }^{3}$ 대경대학교 임상병리학과, ${ }^{4}$ 대구한의대학교 의과학대학 임상병리학과, \\ 5 세명대학교 임상병리학과
}

\begin{abstract}
Menadione is known as an anti-tumor factor. Many studies have reported the potential anti-cancer role of menadione against a range of cancer cell lines. In this study, the anti-cancer effects of menadione and the underlying molecular signaling involved in apoptosis was investigated in gastric cancer cell lines. The menadione treatment decreased the cell viability of MKN45 gastric cancer cells. The decreased cell viability was attributed to the induction of apoptosis, which was confirmed by the results indicating the activation of caspase -3 and -7 and the cleavage of PARP in Western blotting. The upstream regulatory molecules involved in apoptosis were investigated further and it was discovered that menadione reduced the expression of survivin, an inhibitor of upstream apoptosis proteins. In addition, a transcription factor $\beta$-catenin, which is known to regulate survivin expression, was down-regulated by menadione. A previous report showed that menadione inhibited XIAP expression to induce apoptosis and induced G2/M cell cycle arrest in AGS cells. This study elucidated another inhibitory mechanism of menadione against gastric cancer cells in a different cell line. Although further studies will be needed, the inhibitory mechanism demonstrated in this study will help better understand the anti-cancer effects of menadione.
\end{abstract}

Key words: Apoptosis, $\beta$-catenin, Menadione, MKN45 cells, Survivin

This is an Open Access article distributed under the terms of the Creative Commons Attribution Non-Commercial License (http://creativecommons.org/licenses/by-nc/4.0) which permits unrestricted non-commercial use, distribution, and reproduction in any medium, provided the original work is properly cited.

Copyright @ 2019 The Korean Society for Clinical Laboratory Science. All rights reserved.

\section{${ }^{\dagger}$ These authors contributed equally to this work as co-first authors.}

Corresponding author: Jong-Bae Kim

Department of Biomedical Laboratory Science, College of Health Sciences, Yonsei University, 1 Yonseidae-gil, Wonju 26493, Korea

Tel: 82-33-760-2423

Fax: 82-33-760-2561

E-mail: kimjb70@yonsei.ac.kr

ORCID: https://orcid.org/0000-0002-6502-2281

Received: November 8, 2018

Revised: November 29, 2018

Accepted: November 29, 2018

\section{INTRODUCTION}

Naphthoquinones are widespread in nature and synthetic forms of naphthoquinones also exist. Menadione is a synthetic form of naphthoquinones which is also called vitamin K3. As a vitamin K, menadione can play its role for maintenance of blood clotting and bone formation $[1,2]$. There have been various reports suggesting that menadione induces apoptosis in cancer cells. Induction of apoptotic cell death by menadione has been reported on 
several types of cancer cells including lung cancer, breast cancer, hepatocellular carcinoma, pancreatic cancer and ovarian cancers [1, 3-6]. Menadione induced apoptotic cell death by activation of caspase- 3 on hepatocellular carcinoma cells [1]. Activation of caspase-3 and cleavage of PARP by menadione was also observed in pancreatic cancer according to Osadaet al [4]. In ovarian cancer cells, menadione decreased Bid, Bcl-2, Bcl-xL, and survivin protein levels; increased Bax levels; increased release of cytochrome c; activated of caspases (-8, -9 , and -3$)$; and increased cleavage of PARP-1 [3].

Activation of apoptotic cascade is regulated by numerous pro-apoptotic and anti-apoptotic molecules [7]. Bcl-2 family proteins are one of the classical regulatory molecules of apoptosis, and there are at least $15 \mathrm{Bcl}-2$ family members in mammals which include both pro-apoptotic and anti-apoptotic proteins [7, 8]. Bcl-2 is an anti-apoptotic protein and $\mathrm{Bcl}-2$-associated $\mathrm{X}$ protein (BAX) and Bcl-2-associated killer (BAK) are typical pro-apoptotic BCL-2 family proteins both of which are normally sufficient for cell death[7,8]. Moreover, there is another family of proteins named inhibitors of apoptosis protein (IAP) which plays a critical role in the regulation of apoptosis by inhibiting function of caspases [7, 9].

Survivin is a member of IAP family proteins and it is also called baculoviral inhibitor of apoptosis repeat-containing 5 (BIRC5) [10]. This protein is produced by the BIRC5 gene in human [10]. In contrast to the structure of other IAP family proteins this protein is lack of C-terminal RING finger domain, though it possesses a BIR domain [11, 12]. The survivin protein functions to inhibit apoptotic pathway and negatively regulates apoptosis of the cells [13-15]. Survivin interacts with caspase-3 and 7, an effector caspases of apoptotic pathway [13-15]. Survivin expression is regulated by the cell cycle and is highly expressed in the G2/M phase of the cell cycle to support the cell division [12]. This cell cycle-dependent expression of survivin is due to the cell cycle-dependent element in the promoter of survivin gene that typically present in genes expressed in G2/M phase such as cyclin A and cyclin B [12, 16]. During G2/M phase of the cell cycle, survivin localizes to the mitotic spindle and may play a contributing role in regulating mitosis $[12,17]$.

This study was conducted to evaluate the anticancer effect of menadione and to demonstrate the molecular signaling involved in apoptosis in human gastric cancer cell lines.

\section{MATERIALS AND METHODS}

\section{Materials}

RPMI 1640 medium, DMEM medium, fetal bovine serum (FBS), streptomycin-penicillin, and trypsin-EDTA were obtained from BRL Life Technologies (Grand Island, NY, USA). EZ-Cytox cell viability assay kit was purchased from Daeil Lab Service (Seoul, Korea). Trizol reagent, random hexamer, and MMLV-RT were purchased from Invitrogen (Carlsbad, CA, USA). Protease inhibitor cocktail were obtained from Sigma-Aldrich (Saint Louis, MO, USA). Antibodies to detect caspase-3, caspase-7, PARP, $\beta$-catenin and survivin were purchased from Cell Signaling Technology (Danvers, MA, USA) and $\beta$-actin antibody was purchased from Santa Cruz Biotechnology (Dallas, TX, USA).

\section{Cell culture}

MKN45 cells were cultured in RPMI 1640 medium supplemented with $10 \%$ fetal bovine serum and streptomycin-penicillin (100 $\mu \mathrm{g} / \mathrm{mL}$ and $100 \mathrm{IU} / \mathrm{mL})$. AGS cells were cultured in DMEM medium supplemented with $10 \%$ fetal bovine serum and streptomycin-penicillin (100 $\mu \mathrm{g} / \mathrm{mL}$ and $100 \mathrm{IU} / \mathrm{mL}$ ). All the cells were incubated at $37^{\circ} \mathrm{C}$ in a humidified atmosphere with 5\% $\mathrm{CO}_{2}$. RPMI 1640 medium, DMEM medium, fetal bovine serum (FBS), streptomycin-penicillin, and trypsin-EDTA were obtained from BRL Life Technologies (Grand Island, NY, USA).

\section{WST cell viability assay using EZ-Cytox}

To measure cell viability, MKN45 cells $\left(1 \times 10^{4}\right.$ per well $)$ were plated in 96-well plates. After $24 \mathrm{~h}$, cells were treated with various concentrations of menadione. The cells were then incubated for $24 \mathrm{~h}$ and subjected to water 
soluble tetrazolium salt (WST) assay by using EZ-Cytox cell viability assay kit (Daeil Lab Service, Seoul, Korea) [18]. Ten $\mu \mathrm{L}$ of WST solution was added to the cultured media and incubated in the $\mathrm{CO}_{2}$ incubator for $2 \mathrm{~h}$. Absorbance at 450 $\mathrm{nm}$ was measured by spectrophotometer.

\section{RT-PCR (reverse transcription-polymerase chain reaction)}

To perform RT-PCR RNA was extracted from cells using Trizol reagent (Invitrogen, Carlsbad, CA, USA) as described in the manufacturer's instructions. cDNA was synthesized by reverse transcription with $2 \mu \mathrm{g}$ of total RNA, $0.25 \mu \mathrm{g}$ of random hexamer (Invitrogen) and $200 \mathrm{U}$ of MMLV-RT (Invitrogen) for $50 \mathrm{~min}$ at $37^{\circ} \mathrm{C}$ and $15 \mathrm{~min}$ at $70^{\circ} \mathrm{C}$ [18]. Subsequent PCR amplification using $0.25 \mathrm{U}$ of Taq polymerase was performed in a thermocycler using specific primers [18]. The PCR primer sequences used in this study are as follows: survivin forward 5'-AGCCCTTTCTCAAGGACCAC-3' and reverse 5'-GCACTTTCTTCGCAGTTTCC-3', $\beta$-catenin forward 5'-TTGAAGTATACCATACAACTG-3' and reverse 5'-GCAGCATCAAACTGTGTAGAT-3', and GAPDH forward 5'-CGGGAAGCTTGTCATCAA TGG-3' and reverse 5'-GGCAGTGATGGCATGGACTG-3’.

\section{Western blotting}

Proteins were collected from cells and subjected to Western blotting. MKN45 or AGS cells were washed with PBS and then lysed at $4^{\circ} \mathrm{C}$ with lysis buffer containing $1 \%$ Triton X-100 and protease inhibitor cocktail. The cell lysates were then centrifuged and the supernatants were collected. The proteins were separated by SDS-polyacrylamide gel electrophoresis and transferred to a nitrocellulose membrane. The membrane was incubated with optimal concentrations of primary antibody at $4^{\circ} \mathrm{C}$ overnight and then incubated with the appropriate secondary antibody for $2 \mathrm{~h}$ at room temperature. The immune-labeled proteins were visualized using ECL. Antibodies to detect caspase-3, caspase-7, PARP, survivin and $\beta$-catenin were purchased from Cell Signaling Technology (Danvers, MA, USA) and $\beta$-actin antibody was purchased from Santa Cruz Biotechnology (Dallas, TX, USA).

\section{RESULTS}

\section{Menadione reduces cell viability of MKN45 gastric cancer cell line}

The inhibitory effect of menadione on the gastric cancer cells was evaluated. We treated menadione to gastric cancer cell line and assessed changes of cell viability. MKN45 was a gastric cancer cell line used in this study. Various concentrations of menadione $(0 \sim 30 \mu \mathrm{M})$ was treated to MKN45 cells for $24 \mathrm{~h}$ and cell viability was measured by WST assay. In our result, cell viability of MKN45 decreased in a menadione dose-dependent manner (Figure 1A). Cell viability of MKN45 decreased to $53.5 \%$ and $25.9 \%$ by $25 \mu \mathrm{M}$ and $30 \mu \mathrm{M}$ of menadione treatment, respectively (Figure 1A). In addition, microscopic examination also has shown that menadione
(A)

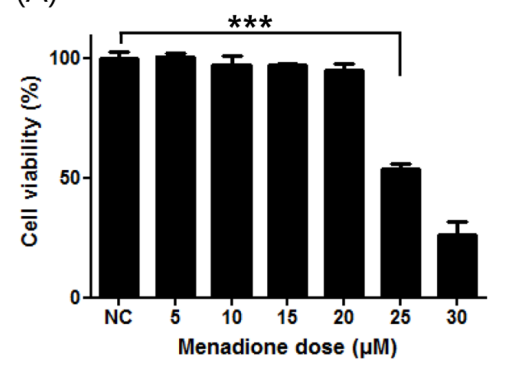

(B)

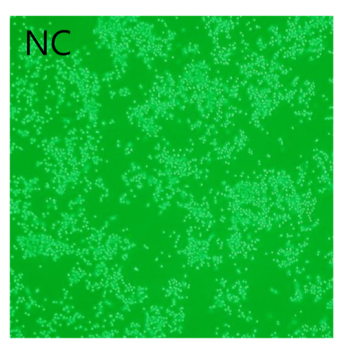

Figure 1. Inhibitory effect of menadione on cell viability of MKN45 gastric cancer cell line. (A) MKN45 gastric cancer cells were treated with indicated dose of menadione (0,10,15, 20, 25, and $30 \mu \mathrm{M})$ for $24 \mathrm{~h}$ and cell viability was measured by WST assay. Data were from three independent experiments and analyzed by unpaired Student's $t$-test ( $\left.{ }^{\star *} p<0.001\right)$. (B) MKN45 cells were treated with or without $30 \mu \mathrm{M}$ of menadione for $24 \mathrm{~h}$ and images were captured using an inverted microscope $(\times 400)$. 
treatment decreases cell confluency (Figure 1B). These results concordantly indicate the inhibitory effects of menadione on cell viability of gastric cancer cells.

\section{Menadione induces apoptosis via activation of caspases in MKN45 cells}

We next investigated whether menadione decreased cell viability of MKN45 cells via induction of apoptosis. MKN45 cells were treated with menadione and the cultured cells were then subjected to Western blotting analysis of PARP and caspases to investigate the presence of apoptosis. In the Western blotting results, it was found that cleaved form of PARP was increased in a menadione dose-dependent manner (Figure 2). Increased amount of cleaved-PARP is a noted indicator of apoptosis, and the cleavage of PARP protein is conducted by so-called

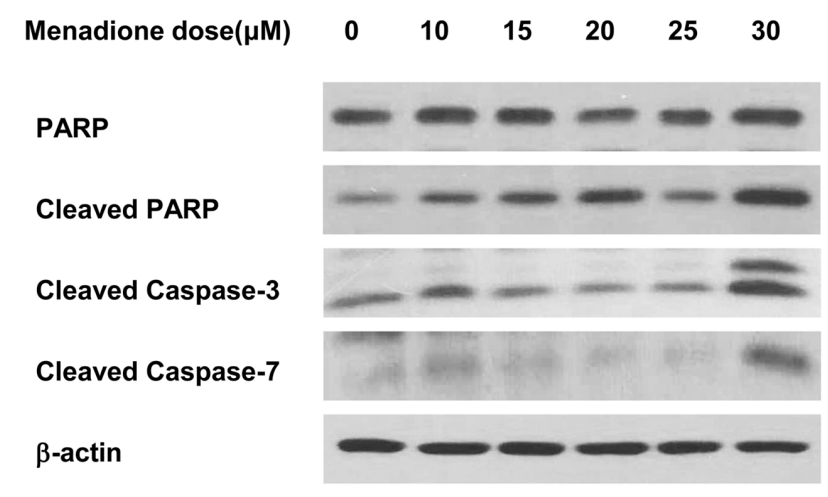

Figure 2. Activation of apoptotic cascade during menadione induced apoptosis of MKN45 cells. MKN45 cells were treated with indicated dose of menadione $(0,10,15,20,25$, and $30 \mu \mathrm{M})$ for $12 \mathrm{~h}$ and the cell lysates were subjected to Western blotting to detect cleavage of PARP, activation of caspase- 3 and 7 . effector caspases such as caspase-3 and caspase-7. Our results also showed that menadione treatment activated both caspase-3 and caspase-7 in MKN45 cells (Figure 2). These results support the idea that menadione reduced cell viability of gastric cancer cells via activation of caspases and induction of apoptosis.

\section{Menadione down-regulates survivin expression consequently inducing apoptosis in gastric cancer cells}

Various molecules are associated with the regulation of caspase activity, and survivin is one of those regulators that inhibit caspase activation. We conducted RT-PCR and Westernblotting to elucidate the upstream regulatory molecule associated with the apoptosis induced by menadione treatment in MKN45 cells. We found that menadione reduced expression of survivin both in mRNA and protein levels (Figure 3A). Down-regulation of survivin was further confirmed in another gastric cancer cell line AGS. Menadione treatment also reduced both mRNA and protein levels of survivin in AGS cells (Figure 3B). In our previous report, we showed that menadione inhibited XIAP expression to induce apoptosis in AGS cells [18]. We also found expression of XIAP was downregulated by menadione in MKN45 cells as it was shown in our previous report (data not shown). Collectively, reduced expression of XIAP and survivin by menadione treatment explains how it activated caspases and the subsequently induced apoptosis in MKN45 cells. TCF/ $\beta$-catenin transcription factor was reported to regulate
(A)

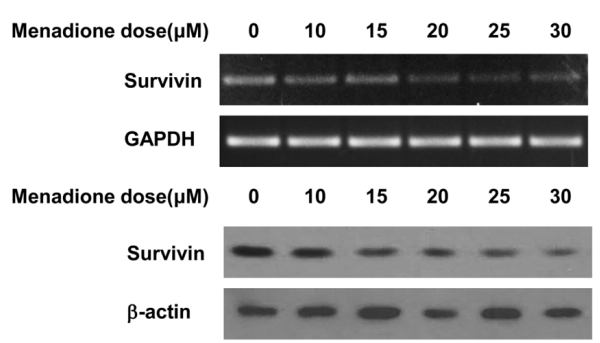

(B)

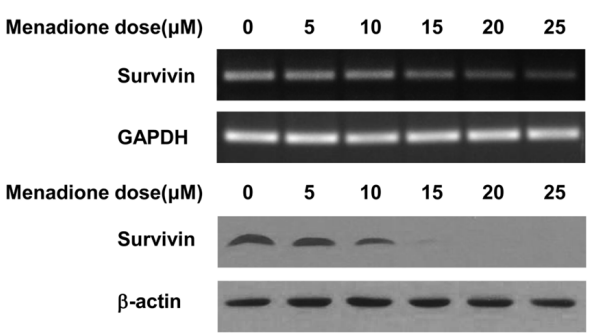

Figure 3. Down-regulation of survivin during menadione induced apoptosis of gastric cancer cell lines. (A) MKN45 cells were treated with indicated doses of menadione $(0,10,15,20,25$, and $30 \mu \mathrm{M})$ for $12 \mathrm{~h}$. RNA was harvested and subjected to RT-PCR to detect survivin mRNA level (upper figure). Cell lysates were collected and subjected to Western blotting to detect survivin protein level (lower figure). (B) AGS cells were treated with indicated doses of menadione $(0,5,10,15,20$, and $25 \mu \mathrm{M})$ for $12 \mathrm{~h}$. Cells were harvested and subjected to RT-PCR (upper figure) and Western blotting (lower figure) to detect survivin mRNA and protein level. 
(A)

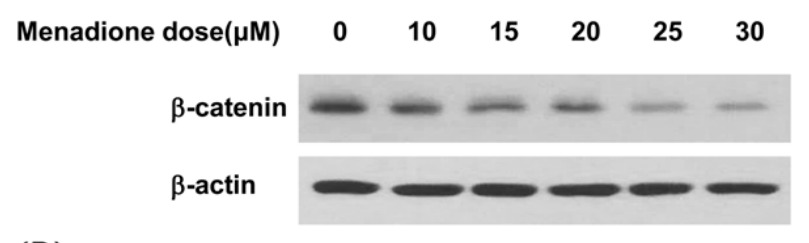

(B)

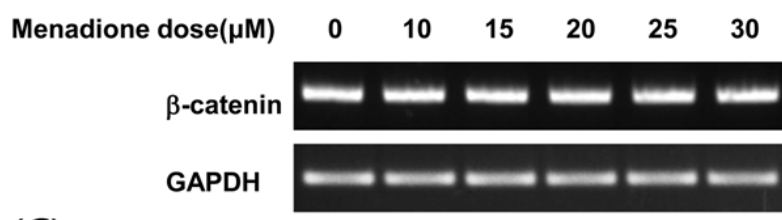

(C)

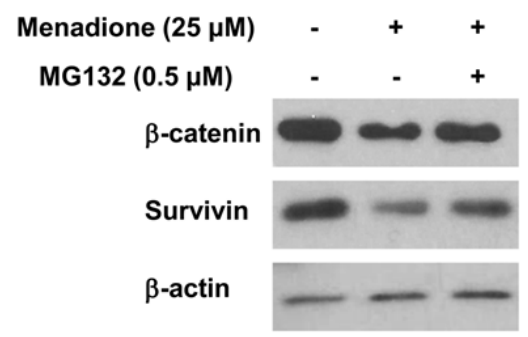

Figure 4. Down-regulation of $\beta$-catenin via proteasome-mediated pathway during menadione-induced apoptosis. (A) MKN45 cells were treated with indicated doses of menadione $(0,10,15,20$, 25 , and $30 \mu \mathrm{M})$ for $12 \mathrm{~h}$. Cell lysates were collected and subjected to Western blotting to detect $\beta$-catenin protein level. (B) Cells were treated as in (A) and subjected to RT-PCR to detect mRNA level of $\beta$-catenin. (C) Menadione $(25 \mu \mathrm{M})$-treated cells were treated with or without MG132 $(0.5 \mu \mathrm{M})$ for $12 \mathrm{~h}$. Cell lysates were collected and subjected to Western blotting to detect $\beta$-catenin protein level.

survivin promoter activity. Thus we investigated protein level of $\beta$-catenin and found that menadione treatment reduced $\beta$-catenin protein level in MKN45 cells (Figure $4 \mathrm{~A})$. However, menadione treatment did not changed mRNA level of $\beta$-catenin (Figure 4B). To elucidate whether menadione down-regulated $\beta$-catenin via proteasome mediated pathway, a proteasome inhibitor MG132 was treated to the cells. The decrease of $\beta$-catenin by menadione was partially alleviated in the cells treated with MG132, and survivin protein level was also partially recovered in concordance (Figure $4 \mathrm{C}$ ). The result showed that proteasome mediated degradation is associated with the decrease of $\beta$-catenin by menadione treatment.

\section{DISCUSSION}

Gastric cancer accounts for $8.5 \%$ of cancer worldwide and $35.4 \%$ of the gastric cancer occurred in Eastern Asia [19, 20]. Prevalent infection of Helicobacter pylori, a class I carcinogen, may have contributed to the high incidence of gastric cancer in Eastern Asia [21]. Park et al. described inhibitory effect of naphthoquinones such as menadione against $H$. pylori. Tariq et al. suggested menadione has gastroprotective effect and reduces gastric ulcer [22]. These reports collectively show the potential availability of menadione for prevention of gastric disease. In this study, inhibitory effect of menadione on MKN45 cells and the inhibitory mechanism have been investigated. Here it has been found that menadione decreased cell viability of MKN45 cells. Decreased cell viability of gastric cancer cells by menadione was mediated by activation of caspase-3, caspase-7, and cleavage of PARP and subsequent induction of apoptosis. Decrease of survivin, which are inhibitor of apoptosis proteins, were involved in the activation of caspases by menadione treatment on gastric cancer cells.

We have elucidated $\beta$-catenin was associated with the down-regulation of survivin by menadione. However, various mechanisms have been reported to regulate survivin expression. The expression of survivin was dependent on the SP1 transcription factor [23]. It was also reported that the expression of survivin is inhibited by p53-mediated transcriptional repression [24]. Persistent activation of Stat3 was reported to induce survivin expression in breast cancer cells [25]. Thus, the other molecular mechanisms may contribute to the down-regulation of survivin in gastric cancer cells treated with menadione.

In addition, we have previously reported that menadione inhibits gastric cancer cell lines by inducing G2/M cell cycle arrest [26]. Survivin expression is regulated by the cell cycle and is highly expressed in the G2/M phase of the cell cycle to support the cell division [12]. This cell cycle-dependent expression of survivin is due to the cell cycle-dependent element in the promoter of survivin gene 
that typically present in genes expressed in G2/M phase such as cyclin A and cyclin B [12, 16]. During G2/M phase of the cell cycle, survivin localizes to the mitotic spindle and may play a contributing role in regulating mitosis [12, 17]. Therefore, we presume that inhibited expression of survivin may also have contributed to the G2/M cell cycle arrest in gastric cancer cells induced by menadione treatment.

The inhibitory effects of menadione on gastric cancer cells and the inhibitory mechanism demonstrated in this study suggests the potential availability of menadione for treatment of gastric cancer. However, further studies still seem to be necessary to completely understand the inhibitory mechanisms and physiological availability in vivo.

\section{요 약}

Menadione은 종양 억제 물질로 알려진 바 있다. 현재 많은 연구에서 다양한 암세포주에 대하여 Menadione의 잠재적인 항암물질로서의 가능성이 보고되었다. 본 연구에서는 $\mathrm{Me}-$ nadione의 항암효과와 세포사멸작용에 연관된 분자신호를 위 암세포주에서 확인하였다. Menadione 처리는 위암세포인 $\mathrm{MKN} 45$ 의 세포생존능을 감소시켰다. 감소된 세포생존능은 Western blotting을 통해 caspase-3 과 caspase-7의 활성화 와 PARP가 cleavage 된 것을 확인함으로써 세포사멸작용이 유 도되었다는 것을 확인했다. 위세포사멸단백질들의 저해제로 작용하는 survivin의 발현을 menadione이 억제한다는 것을 확 인함으로써, 세포사멸과정에 포함된 상위조절인자를 확인했 다. 우리는 survivin 발현을 조절하는 전사인자로 알려진 $\beta^{-}$ catenin 또한 menadione에 의해 하향 조절된다는 것을 확인했 다. 이전 연구에서 우리는 menadione이 세포사멸유도를 저해 는 XIAP의 발현을 억제한다는 것을 확인했으며, menadione이 AGS세포에서 G2/M 세포주기 정체를 유도한다는 것을 확인하 였다. 우리는 또 다른 위암세포주인 MKM45 세포에서 menadione의 이전과 다른 항암 기전을 밝혀냈다. 비록 더 자세 한 연구가 필요하겠지만, 이 연구를 통해 증명된 억제기전은 menadione에 의한 항암효과를 이해하는 데 도움이 될 것으로 사료된다.

\section{Acknowledgements: None \\ Conflict of interest: None}

Author's information (Position): Lee $\mathrm{MH}^{1,2,{ }^{\dagger}}$, Researcher; Kim $\mathrm{J}^{1,2, \dagger}$, Researcher; Cho $\mathrm{Y}^{2}$, Researcher; Kim $\mathrm{DH}^{1}$, Graduate student; Yang JY${ }^{1}$, Graduate student; Kwon $\mathrm{HJ}^{1}$, Graduate student; Park $\mathrm{M}^{3}$, Professor; Woo HJ ${ }^{4}$, Professor; Kim $\mathrm{SH}^{5}$, Professor; Kim JB ${ }^{1}$, Professor.

\section{REFERENCES}

1. Al-Suhaimi E. Molecular mechanisms of leptin and pro-apoptotic signals induced by menadione in HepG2 cells. Saudi J Biol Sci. 2014; 21:582-588.

2. Hassan GS. Menadione. Profiles Drug Subst Excip Relat Methodol. 2013;38:227-313.

3. Kim YJ, Shin YK, Sohn DS, Lee CS. Menadione induces the formation of reactive oxygen species and depletion of GSH-mediated apoptosis and inhibits the FAK-mediated cell invasion. Naunyn Schmiedebergs Arch Pharmacol. 2014;387:799-809.

4. Osada S, Tomita H, Tanaka Y, Tokuyama Y, Tanaka H, Sakashita F, et al. The utility of vitamin K3 (menadione) against pancreatic cancer. Anticancer Res. 2008;28:45-50.

5. Oztopcu-Vatan P, Sayitoglu M, Gunindi M, Inan E. Cytotoxic and apoptotic effects of menadione on rat hepatocellular carcinoma cells. Cytotechnology. 2015;67:1003-1009.

6. Tetef M, Margolin K, Ahn C, Akman S, Chow W, Leong L, et al. Mitomycin $\mathrm{C}$ and menadione for the treatment of lung cancer: a phase II trial. Invest New Drugs. 1995;13:157-162.

7. Igney FH, Krammer PH. Death and anti-death: tumour resistance to apoptosis. Nat Rev Cancer. 2002;2:277-288.

8. Li MX, Dewson G. Mitochondria and apoptosis: emerging concepts. F1000Prime Rep. 2015;7:42.

9. De Almagro MC, Vucic D. The inhibitor of apoptosis (IAP) proteins are critical regulators of signaling pathways and targets for anti-cancer therapy. Exp Oncol. 2012;34:200-211.

10. Span PN, Tjan-Heijnen VC, Heuvel JJ, de Kok JB, Foekens JA, Sweep FC. Do the survivin (BIRC5) splice variants modulate or add to the prognostic value of total survivin in breast cancer? Clin Chem. 2006;52:1693-1700.

11. Chantalat L, Skoufias DA, Kleman JP, Jung B, Dideberg O, Margolis RL. Crystal structure of human survivin reveals a bow tie-shaped dimer with two unusual alpha-helical extensions. Mol Cell. 2000;6:183-189.

12. Sah NK, Khan Z, Khan GJ, Bisen PS. Structural, functional and therapeutic biology of survivin. Cancer Lett. 2006;244: 164-171.

13. Chen X, Duan N, Zhang C, Zhang W. Survivin and tumorigenesis: molecular mechanisms and therapeutic strategies. J Cancer. 2016;7:314-323.

14. Mobahat M, Narendran A, Riabowol K. Survivin as a preferential target for cancer therapy. Int J Mol Sci. 2014; 15:2494-2516.

15. Tang C, Lu YH, Xie JH, Wang F, Zou JN, Yang JS, et al. Downregulation of survivin and activation of caspase-3 
through the PI3K/Akt pathway in ursolic acid-induced HepG2 cell apoptosis. Anticancer Drugs. 2009;20:249-258.

16. Altieri DC, Marchisio PC. Survivin apoptosis: an interloper between cell death and cell proliferation in cancer. Lab Invest. 1999;79:1327-1333.

17. Li F, Ambrosini G, Chu EY, Plescia J, Tognin S, Marchisio PC, et al. Control of apoptosis and mitotic spindle checkpoint by survivin. Nature. 1998;396:580-584.

18. Lee MH, Yang JY, Cho Y, Park M, Woo HJ, Kim HW, et al. Menadione induces apoptosis in a gastric cancer cell line mediated by down-regulation of X-linked inhibitor of apoptosis. Int J Clin Exp Med. 2016;9:2437-2443.

19. Siegel RL, Miller KD, Jemal A. Cancer statistics. CA Cancer J Clin. 2016;66:7-30.

20. Torre LA, Bray F, Siegel RL, Ferlay J, Lortet-Tieulent J, Jemal A. Global cancer statistics, 2012. CA Cancer J Clin. 2015; 65:87-108.

21. Romero-Gallo J, Harris EJ, Krishna U, Washington MK, Perez-Perez GI, Peek RM Jr. Effect of Helicobacter pylori erad- ication on gastric carcinogenesis. Lab Invest. 2008;88:328-336.

22. Tariq M, Al Moutaery A. Menadione protects gastric mucosa against ethanol-induced ulcers. Exp Toxicol Pathol. 2005; 56:393-399.

23. Li F, Altieri DC. Transcriptional analysis of human survivin gene expression. Biochem J. 1999;344(Pt 2):305-311.

24. Esteve PO, Chin HG, Pradhan S. Molecular mechanisms of transactivation and doxorubicin-mediated repression of survivin gene in cancer cells. J Biol Chem. 2007;282:2615-2625.

25. Gritsko T, Williams A, Turkson J, Kaneko S, Bowman T, Huang $\mathrm{M}$, et al. Persistent activation of stat3 signaling induces survivin gene expression and confers resistance to apoptosis in human breast cancer cells. Clin Cancer Res. 2006;12:11-19.

26. Lee MH, Cho Y, Kim DH, Woo HJ, Yang JY, Kwon HJ, et al. Menadione induces G2/M arrest in gastric cancer cells by down-regulation of $\mathrm{CDC} 25 \mathrm{C}$ and proteasome mediated degradation of CDK1 and cyclin B1. Am J Transl Res. 2016; 8:5246-5255. 